Archived version from NCDOCKS Institutional Repository http://libres.uncg.edu/ir/asu/

\title{
Appalacȟnan
}

B O O NE, NORTH CAROLINA

\section{Women's Magazine Coverage Of Heart Disease Risk Factors: Good Housekeeping Magazine, 1997 To 2007}

\author{
By: Carolyn Edy
}

\begin{abstract}
Women, who often turn to magazines for health information, continue to underestimate their risk for heart disease, though it remains the leading cause of death among women in the United States. This textual analysis considered the portrayal of women's risk factors for heart disease as problem and remedy frames within articles published by the highest circulation women's magazine in the U.S., Good Housekeeping, from 1997 to 2007. These findings were then compared with corresponding information endorsed by the American Heart Association. Far from underestimating a woman's risk for heart disease, GH articles seemed to target women at low risk for heart disease, while emphasizing risk factors unique to women. The magazine coverage was largely consistent with American Heart Association information, yet offered a broader range of treatment and prevention strategies that were sometimes contradictory or vague. One significant risk factor, race, was not mentioned in the magazine articles. This review calls for future research to determine the pervasiveness and possible effects of such coverage.
\end{abstract}

Edy, C. (2010) "Women's Magazine Coverage Of Heart Disease Risk Factors: Good Housekeeping Magazine, 1997 To 2007." Version Of Record Available At www.tandfonline.com 


\section{INTRODUCTION}

Heart disease continues to be the leading killer of women in the United States (AHA, 2010). Yet, women's risk for heart disease continues to be underestimated by both women and their health care providers (Mosca et al., 2004; Wenger, 2004). Women are less likely than men to have their cholesterol controlled, are more likely to discover they have heart disease after they have had a heart attack, and are twice as likely as men to die within a year of having a heart attack (Arslanian-Engoren, 2005; Lichtman et al., 2007; Persell et al., 2005; Yawn et al., 2004). Women may not perceive themselves at risk, in part, because of the media's tendency to portray the heart attack as something that happens, without warning, to men (Lefler, 2004). The media have been criticized for idealizing cures and, often, for getting the story wrong about heart disease, even while they are the principal sources of health information for many individuals, including policymakers (Ratzan, 2002). A first step toward addressing this problem is to investigate coverage of health care in the media (Ratzan, 2002; Schwartz \& Woloshin, 2004). More than $40 \%$ of women report getting information about heart disease from magazines-more than from television, health care providers, newspapers, or the Internet (Christian et al., 2007). Women's magazines target women directly and may reach more people with more health information than news magazines (Andsager \& Powers, 1999).

This qualitative textual analysis examined how the problem and remedy frames of heart disease risk factors in women were presented to readers from 1997 to 2007 by Good Housekeeping (GH), the highest circulation women's magazine in the United States, and considered how this information compared with information endorsed by the American Heart Association (AHA), the largest U.S. organization dedicated to promoting awareness about the disease (Gale, 2007; AHA, 2009a).

\section{BACKGROUND}

\section{Framing and Health Care}

Media researchers have, for several decades, studied the ways in which media present, or frame, the important issues of the day for the public (McCombs, 2005; Weaver, 2007). How information is framed affects individual perception and decision-making (Kahneman and Tversky, 1981). Entman has noted that textual frames define problems, diagnose causes, make moral judgments, and suggest remedies-though not every sentence of a text will contain one of these elements, nor will every text contain all of these elements (1993, p. 51). The two most important functions of framing, as identified by Entman (2004), were the focus of this review: defining a problem and endorsing a remedy.

In recent studies, framing has been used and defined in multiple ways to consider how the media present health topics to the public. Topics that have been explored in terms of the framing of media coverage include avian 
flu, cancer, diabetes, obesity, and West Nile virus (Gollust \& Lantz, 2009; Cohen et al., 2008; DeSilva, Muskavitch, \& Roche, 2004; Dudo, Dahlstrom, \& Brossard, 2007; Kim \& Willis, 2007; Lawrence, 2004; Roche \& Muskavitch, 2003). These studies noted the degree to which media frames affect public discourse and public policy. While these studies shared similar methods and revealed overlapping frames, they sought answers to very different questions. Several content analyses have found, generally, that news coverage often provided qualitative information about risks, rather than numeric or statistical information, and news coverage tended to sensationalize the issues and to omit context for weighing risks (Atkin et al., 2008; DeSilva, Muskavitch, \& Roche, 2004; Dudo, Dahlstrom, \& Brossard, 2007; Roche \& Muskavitch, 2003). Content analyses of obesity and diabetes concluded that media coverage most often focused on personal behaviors, rather than systemic or environmental factors (Campo \& Mastin, 2007; Gollust \& Lantz, 2009; Kim \& Willis, 2007; Lawrence, 2004; Rock, 2005).

Though no studies have looked specifically at how women's magazines frame heart disease in terms of problem and remedy frames or in terms of its risk factors alone, several have looked broadly at how media cover heart disease (Clarke, 1992; Clarke \& Binns, 2006; Clarke, van Amerom \& Binns, 2007; Clarke \& van Amerom, 2008;Wharf-Higgins et al., 2006). Studies of heart disease coverage in consumer and news magazines in Canada identified medical, social-structural, and lifestyle frames as those used most frequently (Clarke, 1992; Clarke \& Binns, 2006; Clarke \& van Amerom, 2008). These studies noted the authority given to medical experts, the focus on empowerment, the distortion of relative risk vs. actual risk, and the omission of facts that are more difficult to control-such as the expense of medications and health insurance. They also noted the tendency for magazines to assert facts with confidence, despite contradictory information. Another study evaluated six months of coverage of four priority areas recommended by the AHA in four magazines targeting young women: Shape, Cosmopolitan, Glamour, and Vogue (Turner, Vader, \& Walters, 2008). The magazines covered these four topics-nutrition, physical activity, weight management, and smoking - to varying degrees, but often with no mention of heart disease. Magazine coverage did not contradict AHA guidelines but often presented information that was incomplete or inconsistent (Turner, Vader, \& Walters, 2008).

Thus, studies about the framing of health care coverage note discrepancies between scientific knowledge and media portrayals, as well as the media's tendency to sensationalize diseases and to neglect socioeconomic factors or societal context. They also note that media frames may change the way readers view diseases, in terms of who or what is responsible and who is at greatest risk. The studies of heart disease coverage in women's magazines take a broad look at the narrative discourse and the tone with which heart disease is portrayed. 


\section{The American Heart Association and Heart Disease Risk Factors}

The AHA is the largest voluntary organization in the world dedicated to the prevention and treatment of cardiovascular disease (AHA, 2009a). In 1997, the AHA changed from an organization of many divisions nationwide to a single corporation charged with reaching individuals and "providing credible heart disease and stroke information for effective prevention and treatment" (AHA, 2009b). Today, its mission is "to build healthier lives, free of cardiovascular diseases and stroke," and its tagline, "Learn and Live," reflects its work educating the public about the prevention and treatment of risk factors for heart disease (AHA, 2009b).

Cholesterol, obesity, and smoking were first considered possible risk factors for heart disease in the early 1960s (Fuster \& Gotto, 2000). In 1977, the effects of triglycerides, high-density lipoprotein (HDL) cholesterol, and low-density lipoprotein (LDL) cholesterol were first described (Steinberg, 2006). Soon after, additional risk factors were identified, including diabetes, menopause (for women), and dietary factors (Steinberg, 2006). By 1984, cholesterol was accepted as a major risk factor of heart disease, and $\mathrm{NIH}$ declared cholesterol lowering to be a national public health goal (Steinberg, 2006).

Studies have shown that women and their physicians underestimate women's risk for heart disease, often with dire consequences (Persell et al., 2005). Forty percent of women report getting their information about heart disease from magazines (Christian et al., 2007). Yet, no study has looked at which risk factorswomen's magazines present to their readerswithin featurelength articles about heart disease or how magazines frame these risk factors. Nor has any study compared this framing of heart disease risk factors with information presented by the largest message sponsor, the AHA. Thus, the following research questions were posed:

RQ1: How were women's risk factors for heart disease framed as problems and remedies in feature articles about heart disease in $\mathrm{GH}$ magazine from 1997 to 2007?

RQ2: How did this portrayal compare with information published by the AHA during the same timeframe?

\section{METHOD}

\section{Magazine Articles}

This review included a qualitative textual analysis of $\mathrm{GH}$ feature articles about heart disease from 1997 to 2007. A 10-year period was chosen because women's magazines were unlikely to devote a full feature to a topic more than once a year, so a shorter time period might not have been sufficient to understand the heart disease coverage in $\mathrm{GH}$. Additionally, in 1997 the AHA became a single corporation whose priority was reaching individuals. In the 
mid-1990s, the first recommendations for assessing an individual's "global risk" for heart disease in terms of established risk factors were published in the U.S. (Smith et al., 2004).

Using Gale's magazine directory, GH was identified as having a health care editor, targeting women, and having the highest circulation of women's magazines_reaching nearly five million paid subscribers (Gale, 2007). This review looked only at feature articles about heart disease to learn what this magazine said about risk factors when it devoted considerable space to the topic. First, keyword searches of "heart disease" were attempted in two databases: Academic OneFile and Gale Reference Center Gold. Articles that focused on heart disease and were a minimum of 1,000 words (or at least one page) were chosen. Shorter articles that were grouped on consecutive pages to form a story package of a minimum of 1,000 words also were chosen for analysis. Gale identified $59 \mathrm{GH}$ items, of which one was a short story, eight were advertisements, and 44 either were brief items or mentions or focused on congenital heart disease. This left six feature articles and feature story packages. Academic OneFile identified 42 articles, of which one was a short story, and 23 were discarded because they were brief items or mentions or were focused on congenital heart disease. This left 18 articles; whereas Gale grouped articles constituting one section together, Academic OneFile listed the articles individually. Additionally, each database contained one article that the other did not. Thus, in all, 18 articles remained for analysis.

\section{Data Analysis}

For the purposes of this review, a risk factor was defined as any symptom, sign, condition, attribute, or situation, whether personal or environmental, that was described in the text as something that could exacerbate, cause, or contribute to heart disease. For each of these and other factors found, the researcher noted how the risk factor was described; what numeric values were given to quantify the factor and its risk; what qualitative measures were used (i.e., high-stress occupation, diet high in saturated fat); and in how many paragraphs each risk factor appeared. The recommended prevention and treatment strategies for each risk factor were then considered in a similar manner.

A grounded theory approach was used for this textual analysis, which Charmaz has noted allows researchers to develop "an integrated set of theoretical concepts from their empirical materials that not only synthesize and interpret them but also show processual relationships" (2005, p. 508). Risk factors were grouped into similar categories and analyzed qualitatively to see which risk factors appeared most often, what themes emerged as to how risk factors were described and what prevention or treatment strategies were recommended. As new themes emerged in relation to risk factors as problems or remedies, material was re-read to recode the articles for these themes specifically and, thus, to continually "pin down . . . key themes" represented within the texts (Peräkylä, 2005, p. 870) and to consider stated and underlying interpretations of words, phrases, and sentences until no 
new themes or categories emerged-i.e., until the point of saturation had been reached (Corbin \& Strauss, 2008). For the quantitative portion, which included coding the number of paragraphs in each article and the number of paragraphs mentioning each risk factor, intra-coder reliability was determined to be 88\%, using Scott's Pi (Riffe, Lacy, \& Fico, 2005).

The magazine coverage of risk factors was then compared with information published by the AHA at least six months before each article's publication. Risk factor descriptions, treatments, and prevention parameters were obtained from the women's heart disease consensus panel statements and physician guidelines (representing the collaboration of up to a dozen medical organizations and the endorsement of up to two dozen medical organizations) that were published in Circulation (the journal of the AHA) in 1997 and 2004. These dates were sufficient because no feature articles on heart disease were found for 1997, and the February 2007 article would have been written in 2006; guidelines published before 1997 or after 2006 would have had no bearing on the articles reviewed.

The comparison considered the emphasis placed on each risk factor, as determined by the number of paragraphs that mentioned each risk factor, how each risk factor was described, how the treatment and prevention strategies for each risk factor were described, and which risk factors were included in one article but omitted in another.

\section{FINDINGS}

\section{Magazine Articles and AHA Guidelines}

The $18 \mathrm{GH}$ articles were grouped by the year they were published. Each year, no more than one issue of the magazine contained a feature-length article or package of articles about heart disease. Between 1997 and 2007, $\mathrm{GH}$ published a feature story or feature package of stories on heart disease in the following years: 1999, 2003, 2004, 2005, 2006, and 2007. The first two articles appeared in January and October as four- to five-page feature articles about heart disease. After 2004, heart disease was featured annually in February in a "Special Section" or a "Special Heart Section," in which four to six shorter articles were run together as a story package about heart disease. A variety of risk factors was discussed during the 10-year period, the most frequent being high blood pressure, high cholesterol, diet, and exercise (Figure 1). 


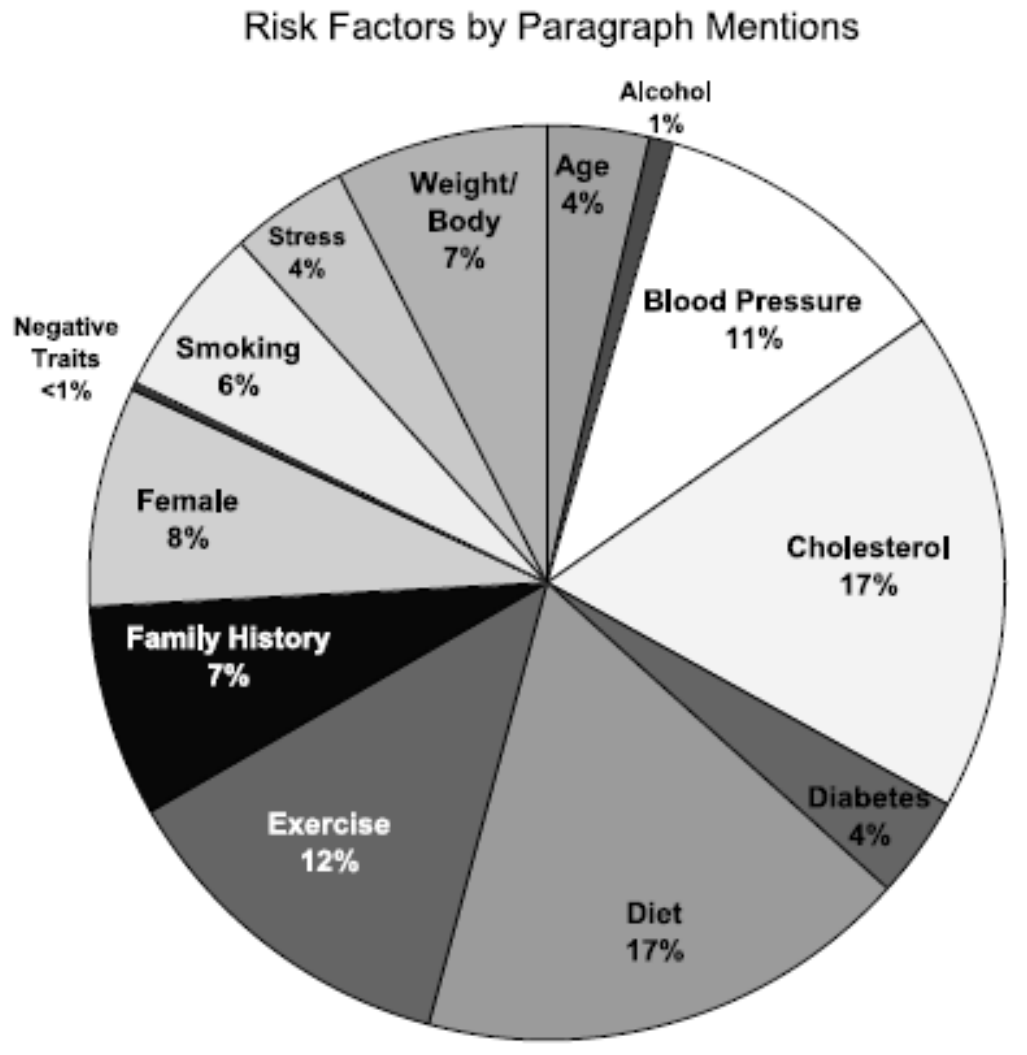

FIGURE 1 Coverage of risk factors in Good Housekeeping magazine feature articles from 1997 to 2007. Shown as percentage of paragraphs that mention the risk factor out of the total number of paragraphs in all feature articles about heart disease.

The AHA publishes information annually about heart disease and its risk factors. (Now called "Heart Disease and Stroke Statistics," the document was called "Heart and Stroke Facts" from 1990 to 2002.) Risk factors and contributing factors recognized by the AHA have included heredity, sex, age, smoking, high blood pressure, high cholesterol, physical activity, obesity/ overweight, and diabetes (Table 1). Descriptions and recommendations for these risk factors were drawn from AHA consensus guidelines published in 1997 and 2004. 
TABLE 1 Problems: Heart Disease Risk Factors Included in the American Heart Association's "Heart and Stroke Facts" and "Heart Disease and Stroke Statistics" from 1993 to 2001

\begin{tabular}{|c|c|c|}
\hline Years & Risk factors & Contributing risk factors ${ }^{*}$ \\
\hline 1993-1998 & $\begin{array}{l}\text { Heredity } \\
\text { Male sex } \\
\text { Increasing age } \\
\text { Cigarette/tobacco smoke } \\
\text { High blood pressure } \\
\text { High blood cholesterol } \\
\text { Physical inactivity }\end{array}$ & $\begin{array}{l}\text { Diabetes } \\
\text { Obesity } \\
\text { Stress (possible risk factor) }\end{array}$ \\
\hline 1999-2001 & $\begin{array}{l}\text { Heredity and race } \\
\text { Male sex } \\
\text { Increasing age } \\
\text { Tobacco smoke } \\
\text { High blood pressure } \\
\text { High blood cholesterol } \\
\text { Physical inactivity } \\
\text { Obesity/overweight } \\
\text { Diabetes Mellitus }\end{array}$ & $\begin{array}{l}\text { Individual response to stress } \\
\text { Hormonal factors } \\
\text { Birth control pills } \\
\text { Excessive alcohol }\end{array}$ \\
\hline $2002-2005$ & $\begin{array}{l}\text { Heredity } \\
\text { Race } \\
\text { Male sex } \\
\text { Increasing age } \\
\text { Tobacco smoke } \\
\text { High blood pressure } \\
\text { High blood cholesterol } \\
\text { Physical inactivity } \\
\text { Obesity/overweight } \\
\text { Diabetes Mellitus }\end{array}$ & $\begin{array}{l}\text { Individual response to stress } \\
\text { Excessive alcohol } \\
\text { Menopause } \\
\text { Certain illegal drugs }\end{array}$ \\
\hline $2005-2007$ & $\begin{array}{l}\text { Heredity (including race) } \\
\text { Male sex } \\
\text { Increasing age } \\
\text { Tobacco smoke } \\
\text { High blood pressure } \\
\text { High blood cholesterol } \\
\text { Physical inactivity } \\
\text { Obesity/overweight } \\
\text { Diabetes Mellitus }\end{array}$ & $\begin{array}{l}\text { Individual response to stress } \\
\text { Excessive alcohol }\end{array}$ \\
\hline
\end{tabular}

Note. Risk factors that changed from one time period to the next are highlighted in bold.

"The AHA defined contributing risk factors as those associated with increased risk of cardiovascular disease but of undetermined significance or prevalence.

\section{Problems and Remedies, by Risk Factor}

Age and sex. In 1997, AHA noted that women's risk of death from heart disease was similar to the risk faced by men 10 years younger, yet diagnosis of heart disease could be more difficult because women could have different 
symptoms and diagnostic tools could be less accurate for women. The AHA also noted that women were more likely to die from a heart attack, despite having no previous symptoms of disease. The $\mathrm{GH}$ articles portrayed age and sex, often together, as risk factors-but it was the risk faced by young women that was emphasized. Increasing age was only discussed in $\mathrm{GH}$ as a risk factor in 2004, with a discussion of the thousands of women under the age of 40 years who die each year of heart attacks and the recognition that the risk only increases as women enter their 40s, 50s, and 60s. GH portrayed being young and female as contributing to risk in 2003 and 2007, while just being female was portrayed as contributing to risk in 1999 and 2004. These articles stressed that because younger women, or women in general, are not considered an at-risk population, they are then at risk for delays and gaps in diagnoses, treatment, and prevention of heart disease and heart attacks. The GH articles' recommended remedies included: (1) learning to recognize and respond to symptoms; and (2) making sure physicians are screening them regularly with relevant tests; relying on the latest genderspecific research; and taking female patients' symptoms, needs, and concerns seriously.

Blood pressure. In 1997, AHA noted a strong association between high blood pressure and risk of heart disease and recommended regular screening and treatment for elevated blood pressure (above 140/90 mm Hg), including beta-blockers, diuretics, weight reduction, and dietary interventions (Table 2). In 2004, the AHA also recommended weight management, exercise, modified diet, sodium reduction, and moderate alcohol consumption for those whose blood pressure was above $120 / 80 \mathrm{~mm} \mathrm{Hg}$. For those whose blood pressure was above $140 / 90 \mathrm{~mm} \mathrm{Hg}$, the AHA also recommended medications, including diuretics. Every $\mathrm{GH}$ feature mentioned high blood pressure but only briefly or within a list of risk factors. Advice for keeping blood pressure in check most often included the recommendation that women get screened regularly and occasionally mentioned risk factor modification (Table 2). 
TABLE 2 Descriptions of High Blood Pressure Problems and Remedies in American Heart Association Physician Guidelines and Good Housekeeping Feature Articles, 1997-2007

\begin{tabular}{|c|c|c|c|}
\hline Year & $\begin{array}{c}\text { American Heart } \\
\text { Association }\end{array}$ & Year & Good Housekeeping \\
\hline 1997 & $\begin{array}{l}\text { Problem: } \mathrm{BP}>140 / 90 \mathrm{~mm} \mathrm{Hg} \\
\text { Remedy: Beta-blockers, diuretics, } \\
\text { weight reduction, and dietary } \\
\text { interventions }\end{array}$ & $\begin{array}{l}1999 \\
2003 \\
2004\end{array}$ & $\begin{array}{l}\text { Problem: } \mathrm{BP}>140 / 90 \mathrm{~mm} \mathrm{Hg} \\
\text { Remedy: Medication; "more } \\
\text { aggressive treatment" } \\
\text { Problem: High blood pressure } \\
\text { Remedy: Check BP at least every } 2 \\
\text { years. } \\
\text { Problem: Pre-hypertension: } 120- \\
\text { 139/ } 80-89 \mathrm{~mm} \mathrm{Hg} \text {; Not OK: } \\
>140 / 90 \mathrm{~mm} \mathrm{Hg} \\
\text { Remedy: Check BP at least every } 2 \\
\text { years. Lifestyle changes, losing } \\
\text { weight, exercise, a heart-healthy } \\
\text { diet, cut back on salt, drugs (best } \\
\text { are diuretics) }\end{array}$ \\
\hline 2004 & $\begin{array}{l}\text { Problem: } \text { Not optimal: } \mathrm{BP}>120 / 80 \\
\text { mm } \mathrm{Hg} \\
\text { High: }>140 / 90 \mathrm{~mm} \mathrm{Hg} \\
\text { Remedy: If not optimal: weight } \\
\text { management, exercise, modified } \\
\text { diet, sodium reduction, moderate } \\
\text { alcohol consumption. If above } \\
140 / 90 \mathrm{~mm} \mathrm{Hg} \text {, also medications, } \\
\text { including diuretics }\end{array}$ & 2005 & $\begin{array}{l}\text { Problem: Super-fat cells from belly } \\
\text { fat gained in middle age } \\
\text { Remedy: Diet of good carbs and } \\
\text { good fats } \\
\text { Problem: Prehypertension: } 120 / 80 \text { to } \\
139 / 80 \mathrm{~mm} \mathrm{Hg} \text {; Hypertension: } \\
\text { 140/90 mm Hg and higher } \\
\text { Remedy: Chemicals in avocados } \\
\text { protect against hypertension. } \\
\text { Problem: "Blood pressure." Family } \\
\text { members with high BP } \\
\text { Remedy: "Take action;" exercise and } \\
\text { nutrition; eat fish, especially oily } \\
\text { types }\end{array}$ \\
\hline
\end{tabular}

Cholesterol. In 1997, AHA recommended low-density lipoprotein (LDL) levels below $100 \mathrm{mg} / \mathrm{dL}$, high-density lipoprotein (HDL) levels greater than $50 \mathrm{mg} / \mathrm{dL}$, and triglyceride levels less than $150 \mathrm{mg} / \mathrm{dL}$ (Table 3). Among women, high LDL or total cholesterol only predicted heart disease in those younger than age 65 years; yet low HDL was a stronger predictor of heart disease death in women than in men (AHA, 1997). In 1997, triglycerides were still controversial, but AHA considered them an important risk factor for women. Little evidence existed in 1997 to support diet or medication to prevent heart disease in healthy women, though AHA noted that treatment appeared to be beneficial for women who already had heart disease. In 2004, AHA advised women with elevated LDL to reduce trans fatty acids, to keep saturated fat to less than $7 \%$ of total calories, and to limit dietary cholesterol to less than $200 \mathrm{mg}$ a day. AHA (2004) recommended therapies to lower LDL, including statins and lifestyle changes, for high-risk women, while recommending therapies such as niacin or fibrates for high-risk women with low HDL. All of the GH articles discussed high cholesterol, giving 
cholesterol, along with diet, the most coverage of all risk factors. $\mathrm{GH}$ articles also mentioned medication for lowering cholesterol each year except 2006. Specific targets for cholesterol levels were included in 1999, 2004, 2006, and 2007. Cholesterol was the risk factor most likely to be described numerically (Table 3). Target levels for total cholesterol and LDL were at their highest, and the target level of HDL was at its lowest in 1999. The 1999 feature described high cholesterol as a warning sign and said that LDL cholesterol "gums up arteries," while HDL clears arteries, and triglycerides are "another type of dangerous blood fat." Remedies proposed included cholesterol-lowering drugs, more aggressive treatment, and eating more healthfully by following a cholesterol-lowering diet that did not include high-fat hot dogs and chips but did include vegetables, fish, and whole grains.

TABLE 3 Numeric Descriptions of Cholesterol Problems and Remedies in American Heart Association Guidelines and Good Housekeeping Feature Articles, 1997 to 2007

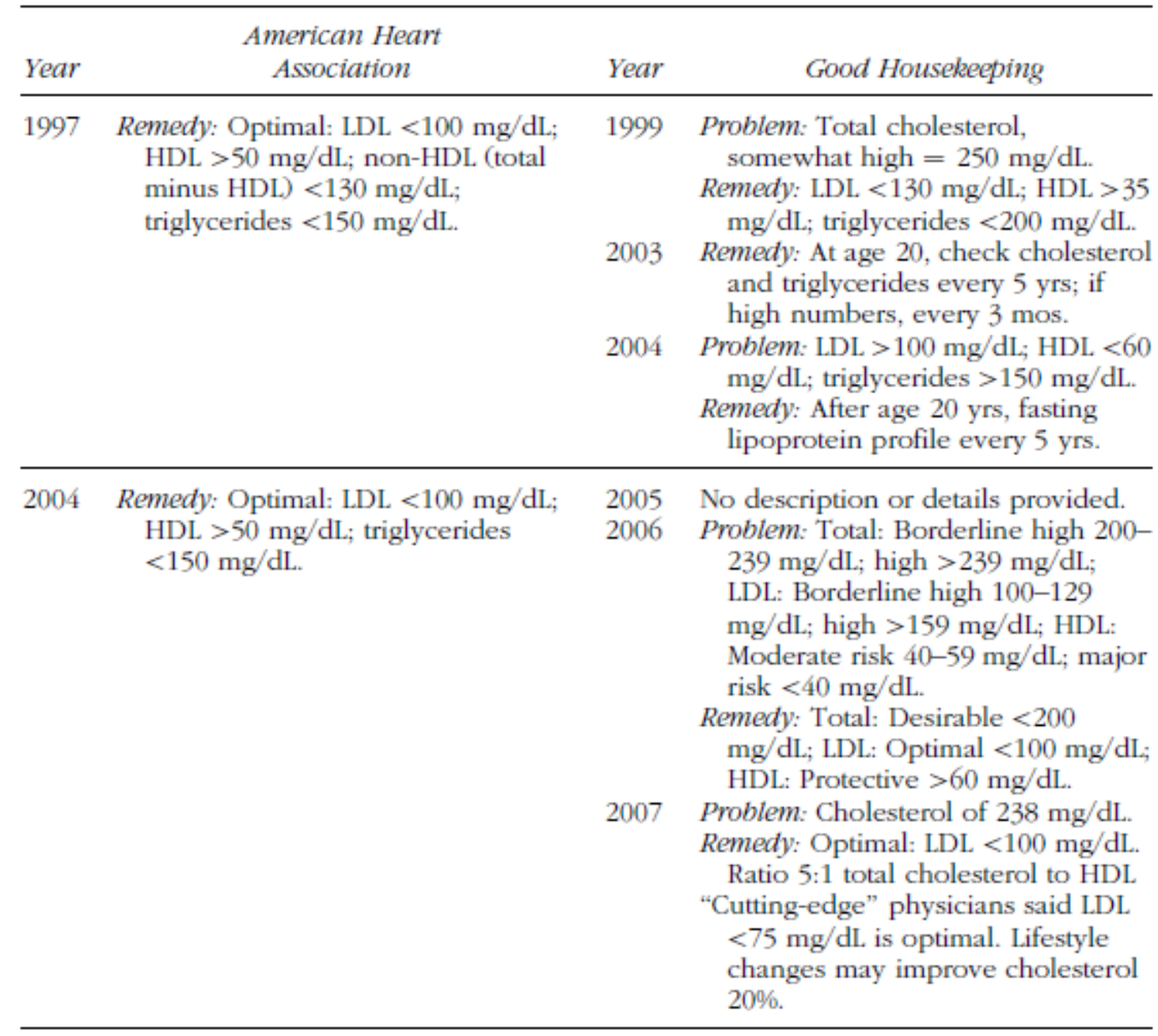


In 2003, a GH article noted that before her heart attack, one woman

favored bacon and sausage and did not eat many fruits or vegetables; afterward, she lowered her cholesterolwith "better eating." This article said statins may be more effective for women than men. The 2004 feature noted that women should know their HDL and triglyceride counts, as they were much stronger predictors of heart attack in women. The article said cholesterollowering drugs work well for women, especially Zetia, a new drug that could reduce LDL with few side effects.

In 2005, a cardiologist said total cholesterol numberswere a poor predictor of heart disease, especially for women; higher numbers could indicate more HDL. Even LDL was not a good predictor unless it was "very, very elevated," the cardiologist noted. The cardiologist also noted that women could ask physicians to test the size of their LDL particles because smaller LDL particles were more likely to get into blood vessel walls. Triglycerides carry fatty acids into the bloodstreamafter a meal, he said, and are a significant risk factor for females. He noted that soon new drugs will raise good cholesterol, but until then daily multivitamins/minerals could reduce bad cholesterol and cut chances of having a heart attack.

In 2006 and 2007, GH credited foods such as alcohol, nuts, avocados, olive oil, and dark European chocolate with lowering LDL levels. The 2006 article announced a cholesterol screening day at Wal-Marts/Sam's Clubs. In 2007, a cardiologist from a "cutting-edge preventive health center" said labs varied, so it was best to track the ratio of total cholesterol to HDL. The remedy was to stay on top of tests, get copies of lab reports, and take action through exercise, a healthy diet, stress reduction, and, for fit women who eat well but have unhealthy cholesterol levels, medication.

Diabetes. In 1997, AHA noted that women with diabetes face three to seven times the risk of heart disease than those without diabetes and, among those with non-insulin dependent diabetes, half of deaths are from heart disease. In 1997 and 2004, AHA recommended medication, exercise, a healthy weight, and other lifestyle changes. The GH articles mentioned diabetes every year except 2005, though just briefly in 2004, 2006, and 2007. In 1999, GH called diabetes the chief cause of one woman's heart attack because it "stiffened and thickened the arteries that send blood to her heart." Low-fat, low-sugar meals were the remedy for diabetes, along with medications to control diabetes. In 2003, GH called diabetes an obvious risk factor that may punish women more than men, increasing a woman's risk of heart disease by three to seven times. Remedies included medication and a low-fat, low-sugar diet. Regular screening for diabetes was only recommended for those with obesity or a family history of diabetes. The $2004 \mathrm{GH}$ feature noted that extra pounds and a sedentary lifestyle could increase risk of diabetes, which was more of a heart disease risk factor in women than in men. In 2006, diabetes was called a risk factor that could be identified with the following blood glucose levels: less than $100 \mathrm{mg} / \mathrm{dL}$ was healthy, $100-125 \mathrm{mg} / \mathrm{dL}$ signaled prediabetes, and $126 \mathrm{mg} / \mathrm{dL}$ or higher was diabetes. In 2007, the feature advised readers to tell doctors about family members who had had diabetes. It also noted that diabetes patients should aim for LDL levels below 70. 
Diet. AHA's dietary recommendations in 1997 included limiting trans fatty acids and saturated fat and eating a diet high in fruits, vegetables, whole grains, and fiber. At that time, AHA noted that it was uncertain whether monounsaturated fat, polyunsaturated fat, or omega-3 fatty acids had an effect on risk of heart disease. AHA also noted thatmoderate intake of alcohol could reduce risk of heart disease, yet it could also raise blood pressure. In 2004, AHA also recommended eating fish and legumes, limiting saturated fat to less than $10 \%$ of daily calories, and limiting daily cholesterol to less than $300 \mathrm{mg}$. The AHA noted that fish was associated with reduced risk of heart disease but, as of 2004, the benefits of other sources of omega-3 fatty acids (such as flaxseed oil or walnuts) remained uncertain. The GH articles included diet as a risk factor each year, always linking it to diabetes, cholesterol, or weight loss. GH offered specific recommendations in 1999, 2005, 2006, and 2007. In 1999, the GH article suggested keeping fat intake to less than $30 \%$ of daily calories, with saturated fat accounting for no more than $10 \%$. In 2005, GH included low-carbohydrate recommendations from the South Beach Diet. In 2006, seven foods were highlighted for reducing risk of heart disease, such as antioxidants in blueberries that "neutralize certain destructive substances that contribute to heart disease." Eating well and being active were said to reduce risk of heart disease by up to $50 \%$. In 2007, a Mediterranean-style diet was said to cut heart risk factors more than AHA's low-fat plan. The article also recommended eating five servings a day of fruits and vegetables, which could reduce heart disease risk by $18.4 \%$.

Exercise. AHA noted in 1997 that exercise could reduce risk of heart disease in women by 50\%. In 1997, the AHA recommended at least 30 minutes of moderate-intensity physical activity, such as brisk walking, on mostbut preferably all-days (Table 4). The GH articles mentioned exercise, to varying degrees, each year. In 1999 and 2003, GH described lack of exercise as a characteristic of two women before their heart attacks, while GH noted that doing yoga, taking long walks, playing sports, and cycling to work were among positive changes made by women after their heart attacks. The 1999 article said that one woman's physician should have prescribed an exercise program before her heart attack. Two other women, whom GH profiled in 2003 and 2007, had suffered heart attacks while exercising. In 2004, GH recommended that women over 50 get an exercise stress test before beginning an exercise program because women who scored poorly on these tests were 3.5 times more likely to die of heart disease. The 2007 article said even thin women need to exercise and exercise may make belly fat less risky by shrinking the size of fat cells (Table 4). 
TABLE 4 Exercise Recommendations (remedies) in American Heart Association-Endorsed Physician Guidelines and Good Housekeeping Feature Articles, 1997-2007

\begin{tabular}{|c|c|c|c|}
\hline Year & $\begin{array}{c}\text { American Heart } \\
\text { Association }\end{array}$ & Year & Good Housekeeping \\
\hline 1997 & $\begin{array}{l}\text { Accumulate at least } 30 \text { min moderate } \\
\text { exercise, such as brisk walking, } \\
\text { on most, preferably all, days. }\end{array}$ & $\begin{array}{l}1999 \\
2003 \\
2004\end{array}$ & $\begin{array}{l}\text { Get moving. } \\
\text { Work out } 30 \mathrm{~min}, 3-5 \text { times/wk. } \\
\text { No specific recommendations. } \\
30 \text { min daily brisk walking. }\end{array}$ \\
\hline 2004 & $\begin{array}{l}\text { Even moderate-intensity activity, } \\
\text { including brisk walking, is } \\
\text { associated with substantial risk } \\
\text { reduction. } \\
30 \text { min moderately intense physical } \\
\text { activity most days of the week. }\end{array}$ & 2005 & $\begin{array}{l}\text { "Less is more." } \\
\text { Biggest benefit is in first } 20-30 \text { min. } \\
\text { Women need to work up a sweat. } \\
\text { Walking at least } 20 \text { min } 3-5 \\
\text { times/wk. } \\
\text { Being active can cut risk by } 50 \% \text {. } \\
\text { Any workout is better than none. } \\
\text { Push slightly beyond comfortable. } \\
\text { Ideal is } 30-60 \text { min, most days. } \\
\text { Need moderate-intensity, e.g., brisk } \\
\text { walking or dancing, and more } \\
\text { active, e.g., jogging or biking } \\
\text { uphill. } \\
\text { Push only slightly beyond } \\
\text { comfortable. } \\
\text { Ideal is at least } 30 \text { min, most days. }\end{array}$ \\
\hline
\end{tabular}

Race and family history. AHA noted in 1997 and 2004 that knowing an individual's medical family history was important as a means of knowing an individual's risk of heart disease. In 2004, AHA noted that patients were at increased risk if they had a first-degree relative who had had heart disease before the age of 55 years, if a man, and the age of 65 years, if a woman. The AHA also noted in 1997 and 2004 that risk of heart disease varied significantly by race. AHA noted in 1997 that the death rate for heart disease among black women was $34 \%$ higher than among white women, while black men only faced a $5 \%$ higher rate than white men. The GH articles never mentioned race. Family history was included as a risk factor each year except 2004. It was described (in 1999) as being beyond one woman's control; as signifying that an individual was at risk (in 2006 and 2007) or at high risk (in 2003); and as being the cause for cholesterol problems in women who ate well and were physically fit (in 2007). In 2005, the risk was explained further and numerically: the risk doubled for someone whose father had heart disease before age 55 years or whose mother had heart disease before 65 years; risks quadrupled for those whose sibling had heart disease before 55 years. Beyond knowing one's family history, other remedies included blood testing (2003), medication (if cholesterol was high despite diet and exercise) (2007), and talking to a physician about preventive lifestyle changes (2005). 
Smoking. The AHA noted in 1997 that smoking increased an individual's risk by two to four times, that among middle-aged women, more than half of heart attacks could be attributed to tobacco, and that smoking was the leading preventable cause of heart disease in women. The AHA also noted that those who quit would reduce their risk of heart disease within months; after three to five years their risk would be the same as if they had never smoked. The $\mathrm{GH}$ articles mentioned smoking as a risk factor, briefly, in every feature except in 2006. The articles did not provide advice for quitting, though one article included a heart attack victim who said she was able to quit with God's help.

Stress and negative personality traits. In 1997, AHA guidelines noted a need for more studies on stress reduction and psychosocial interventions. In 2004, AHA guidelines advised physicians to have heart disease patients evaluated and, if indicated, treated for depression. In 1999, GH urged readers to reduce stress, which could lead to smoking or eating more. In 2003, a "poster child for women with endangered hearts" was said to have "also had a high-stress job" before her heart attack. After her heart attack, she switched jobs, "changed her whole attitude," and stopped "sweating the small stuff." In 2004, "daily stress level" was a risk factor because "stress and anger trigger the release of a cascade of hormones that can damage your blood vessels." The recommended remedy was solitude, taking 30 minutes daily to recharge. Also in 2004, GH called negative personality traits-feelings of hostility, cynicism, anger, mistrust, and aggression-risk factors that were riskier than high blood pressure, smoking, or high cholesterol. Stress was not included in GH articles in 2005 or 2006. In 2007, stress was called an underestimated risk factor, and reducing stress was among the traits of those "at borderline risk" for heart disease. This feature said that it was a risk if one's blood pressure rose when stressed at work or when stuck in traffic.

Weight, body mass, and body shape. In 1997, AHA guidelines stated that obesity, especially around the abdomen, was an important risk factor for heart disease in women, who should have a body mass index between 18.5 and 24.9 and a waistline of less than 35 inches. In 2004, guidelines also noted that women should exercise and limit calories to maintain/attain these measurements. All of the $\mathrm{GH}$ articles mentioned excess weight, body mass index, or body shape, or some combination of the three. In 1999, GH advised women to keep their weight in check and to strive for a BMI of 21 to 25 . In 2003, a heart attack victim was deemed a "poster child for women with endangered hearts" because of several risk factors, including being 15 pounds overweight. In 2004, a cardiologist told GH that extra pounds and a sedentary lifestyle really "pump up" a woman's risk for heart disease and diabetes, and she would advise an overweight patient to find ways to sneak in exercise and throw out excess calories. Elsewhere, the $\mathrm{GH}$ feature stated that as weight goes up, so does heart disease risk, especially if weight is carried around the abdomen. In 2005, the cardiologist and author of the South Beach Diet said weight carried around the waist could set "the stage for heart disease," even if a patient is generally slim, because "super-fat cells" from belly fat gained in middle age increase insulin levels, cholesterol levels, and blood pressure. But, he said, women whose fat is concentrated in their hips 
and thighs often have perfectly healthy blood chemistries. He recommended choosing good carbohydrates and good fats. The feature in 2006 downplayed weight as a risk factor, stating that the waistline provided a better measure of risk than a height/weight measure and that waist circumferences greater than 35 inches put women at highest risk. Use of a tape measure was said to be one indicator that a physician was heart smart. In 2007, the feature noted that though hauling around too much body fat was "hard on the heart," doctors should look more closely at body shape. Apple-shaped people, with more fat around the abdomen, were at greater risk than pear-shaped people. The remedy proposed by the 2007 feature was to get moving because diet alone would not do it, but exercise could; additionally, the feature noted, exercise might make belly fat less risky by shrinking the size of the fat cells around the abdomen.

\section{DISCUSSION}

This review considered $\mathrm{GH}$ articles about heart disease in terms of their two most important functions, as identified by Entman (2004): defining a problem and endorsing a remedy. The problems within the text were defined as the risk factors of heart disease, and the remedies were defined as the strategies for the prevention and treatment of heart disease. Far from focusing only on cholesterol as a risk factor and overlooking other factors, $\mathrm{GH}$ has covered a wide range of risk factors in the past decade. The risk factors (problems) and the strategies for prevention and treatment (remedies) portrayed by $\mathrm{GH}$ were, for the most part, consistent with the information published by the AHA. In 2004, the magazine began to feature heart disease annually in February, which has been officially known as "American Heart Health" month since 1963, when Congress first signed into law the AHA-drafted proclamation.

Often, recommendations in $\mathrm{GH}$ have been far more specific, even more stringent, than those recommended by AHA. Race was the one risk factor recognized by the AHA that was never mentioned in $\mathrm{GH}$. The leading preventable risk factor, smoking, was mentioned only briefly and no remedies, or ways to quit smoking, were suggested. While information in the articles overall was consistent with AHA information, the way in which it was presented was often vague, incomplete, or contradictory. Advice included both very specific suggestions, such as "eat an avocado," and very empty recommendations, such as "take action." Exercise was suggested as a remedy, but articles also portrayed women who suffered heart attacks while exercising. Most of the articles reflected a certain distrust of physicians, who might not have a tape measure on hand, who might not know the latest tests, or who might underestimate women's risks. At the same time, the articles reflected a strong reliance on physicians because much of the advice provided was dependent upon a physician's cooperation or a woman's discussion with her own physician. Lastly, GH has emphasized that women are at risk because they are not an at-risk population for heart disease, and thus their providers, or women themselves, might overlook prevention and treatment strategies. All of the women featured in the articles were in their 40 s and 50s. The articles described several women who had no risk factors and yet suffered heart attacks. Rather than underestimating women's risk, 
the articles seemed to overemphasize the risk of heart disease for women who were at low risk for the disease.

\section{LIMITATIONS}

This review took a close look at one aspect of magazine coverage of heart disease to reveal which risk factors and which methods of prevention and treatment were being presented to readers of one national women's magazine. This review did not reveal why GH magazine more often covered certain risk factors while overlooking others, nor did this review reveal why the magazine included certain prevention or treatment recommendations and not others. Additionally, the comparison of risk factor coverage in magazines with recommendations from the AHA has limited usefulness. This review did not consider the value of recommendations, nor did it consider elements of the articles that were not risk factors or prevention/treatment strategies for risk factors. Therefore, many remedies discussed in the articles, such as surgery or daily aspirin, were not included because they were not discussed as risk factors. Lastly, as a textual analysis, this review could only describe and evaluate magazine content and could not reveal anything about possible effects of the material on readers.

This review lays the groundwork for a future study of greater scope, within a range of women's magazines that could analyze graphics along with text and consider how coverage of risk factors differs by magazine or target audience. A future study could also look at magazine coverage of heart disease since the 2007 launch of the AHA campaign, "Go Red for Women." Lastly, future studies should consider the effects of magazine content on audiences, as well as the decision-making processes of reporters and editors who produce the magazine content.

\section{REFERENCES}

American Heart Association (AHA). 1997. Cardiovascular disease in women: A statement for healthcare professionals from the American Heart Association. Circulation 96:2468-82.

American Heart Association (AHA). 2004. Evidence-based guidelines for cardiovascular disease prevention in women. Circulation 109:672-93.

American Heart Association (AHA). 2009a. About the American Heart Association. Retrieved December 14, 2009, from http://americanheart.mediaroom.com/ index.php?s=20

American Heart Association (AHA). 2009b. History of the American Heart Association. Retrieved December 14, 2009, from http://www.americanheart.org/ presenter.jhtml?identifier $=10860$

American Heart Association (AHA). 2010. Heart disease and stroke statistics-2010 update. Dallas, TX: American Heart Association. 
Andsager, J. L., and A. Powers. 1999. Social or economic concerns: How news and women's magazines framed breast cancer in the 1990s. Journalism \& Mass Commun 76:531-50.

Arslanian-Engoren, C. 2005. Treatment-seeking decisions of women with acute myocardial infarction. Women \& Health 42:53-70.

Atkin, C. K., S. W. Smith, C. McFeters, and V. Ferguson. 2008. A comprehensive analysis of breast cancer news coverage in leading media outlets focusing on environmental risks and prevention. J Health Commun 13:3-19.

Campo, S., and T. Mastin. 2007. Placing the burden on the individual: Overweight and obesity in African American and mainstream women's magazines. Health Commun 22:229-40.

Charmaz, K. 2005. Grounded theory in the 21st Century: Applications for advancing social justice studies. In Handbook of qualitative research, eds. N. K. Denzin and Y. S. Lincoln. Thousand Oaks, CA: Sage.

Christian, A. H., W. Rosamond, A. R. White, and L. Mosca. 2007. Nine-year trends and racial and ethnic disparities in women's awareness of heart disease and stroke: AHA national study. J Women's Health 16:68-81.

Clarke, J. N. 1992. Cancer, heart disease, and AIDS: What do the media tell us about these diseases? Health Commun 4:105.

Clarke, J. N., and J. Binns. 2006. The portrayal of heart disease in mass print magazines, 1991-2001. Health Commun 19:39-48.

Clarke, J., G. van Amerom, and J. Binns. 2007. Gender and heart disease in mass print media: 1991, 1996, 2001. Women \& Health 45:17-35.

Clarke, J., and G. van Amerom. 2008. Mass print media depictions of cancer and heart disease: Community versus individualistic perspectives? Health Soc Care Comm 16:96-103.

Corbin, J., \& A. Strauss. 2008. Basics of qualitative research. Thousand Oaks, CA: Sage.

Cohen, E. L., C. A. Caburnay, D. A. Luke, G. W. Brown, S. Rodgers, G. T. Cameron, et al. 2008. Cancer coverage in general-audience and black newspapers. Health Commun 23:427-35.

DeSilva, M., M. A. T. Muskavitch, and J. P. Roche. 2004. Print media coverage of antibiotic resistance. Science Commun 26:31-43.

Dudo, A. D., M. F. Dahlstrom, and D. Brossard. 2007. Reporting a potential pandemic: A risk-related assessment of avian influenza coverage in U.S. newspapers.

Science Commun 28:429-54. 
Entman, R. M. 1993. Framing: Toward clarification of a fractured paradigm. J Commun 43:51.

Entman, R. M. 2004. Projections of power: Framing news, public opinion, and U.S. foreign policy. Chicago, IL: University of Chicago Press.

Fuster, V., and A. M. Gotto, Jr. 2000. Risk reduction. Circulation 102:94-102.

Gollust, S. E., and P. M. Lantz. 2009. Communicating population health: Print news media coverage of type 2 diabetes. Soc Science \& Med 69:1091-8.

Gale Directory of Publications. 2007. Detroit, MI: Gale Research.

Heart and Stroke Facts. 1993-2001. Dallas, TX: American Heart Association.

Kim, S., and L. A. Willis. 2007. Talking about obesity: News framing of who is responsible for causing and fixing the problem. J Health Commun 12:359-76.

Klaidman, S. 1991. Health in the headlines. New York, NY: Oxford University Press. Lawrence, R. G. 2004. Framing obesity: The evolution of news discourse on a public health issue. Harvard Int J Press/Politics 9:56-75.

Lefler, L. L. 2004. Perceived risk of heart attack: A function of gender? Nursing Forum 39:18-26.

Lichtman, J., N. Allen, E. Watanabe, Z. Lin, S. Zarich, B. Hart, et al. 2007. Abstracts from the 8th scientific forum on quality of care and outcomes research in CVD and stroke. Circulation 115:e550-e602.

McCombs, M. 2005. A look at agenda-setting: Past, present and future. Journalism Studies 6:543-57.

Mosca, L., A. Ferris, R. Fabunmi, and R. M. Robertson. 2004. Tracking women's awareness of heart disease: American Heart Association national study. Circulation 109:573-9.

Persell, S., S. Maviglia, D. Bates, and J. Ayanian. 2005. Ambulatory hypercholesterolemia management in patients with atherosclerosis. J Gen Intern Med 20:

123-30.

Peräkylä, A. 2005. Analyzing talk and text. In Handbook of qualitative research, eds. N. K. Denzin and Y. S. Lincoln. Thousand Oaks, CA: Sage.

Ratzan, S. C. 2002. Public health at risk: Media and political malpractice. J Health Commun 7:83-5.

Riffe, D., S. Lacy, and F. G. Fico. 2005. Analyzing media messages: Using quantitative content analysis in research. Mahwah, NJ: Erlbaum.

Roche, J. P., and M. A. T. Muskavitch. 2003. Limited precision in print media communication of West Nile virus risks. Science Commun 24:353. 
Rock, M. 2005. Diabetes portrayals in North American print media: A qualitative and quantitative analysis. Am J Public Health 95:1832-8.

Schwartz, L. M., and S. Woloshin. 2004. The media matter: A call for straightforward medical reporting. Ann Intern Med 140:226-8.

Smith, S., R. Jackson, T. Pearson, V. Fuster, S. Yusuf, O. Faergeman, et al. 2004. Principles for national and regional guidelines on CVD prevention. Circulation 109:3112-21.

Steinberg, D. 2006. An interpretive history of the cholesterol controversy, part V. J Lipid Research 47:1339-51.

Turner, M., A. Vader, and S. Walters. 2008. An analysis of cardiovascular health information in popular young women's magazines: What messages are women receiving? Am J Health Promo 22:183-6.

Tversky, A., and D. Kahneman. 1981. The framing of decisions and psychology of choice. Science 211:453-8.

Weaver, D. H. 2007. Thoughts on agenda setting, framing, and priming. J Communic 57:142-7.

Wenger, N. K. 2004. You've come a long way, baby: Cardiovascular health and disease in women: Problems and prospects. Circulation 109:558-60.

Wharf-Higgins, J., P. J. Naylor, T. Berry, B. O'Connor, and D. McLean. 2006. The health buck stops where? Thematic framing of health discourse to understand the context for CVD prevention. J Health Commun 11:343-58.

Yawn, B., P. Wollan, S. Jacobsen, G. Fryer, and V. Roger. 2004. Identification of women's coronary heart disease and risk factors prior to first myocardial infarction. J Women's Health 13:1087-1100. 